\title{
The gains and pains of small and medium-scale enterprises (SMEs): the way forward for entrepreneurship development in Nigeria
}

\author{
Gbemi Oladipo Olaore \\ Department of Business Administration, University of Lagos, Lagos, Nigeria \\ Bimbo Onaolapo Adejare \\ Department of Business Administration, School of Economics and Management, \\ University of Minho, Braga, Portugal, and \\ Ekpenyong Ekpenyong Udofia \\ Department of Business Administration, University of Lagos, \\ Lagos, Nigeria
}

Small and medium-scale enterprises

Received 23 September 2020 Revised 8 December 2020 Accepted 8 December 2020

\begin{abstract}
Purpose - The purpose of this study is to assess the role of small and medium-scale enterprises (SMEs) as a catalyst to all things good in great economies; however, sadly, Nigeria has been unable to unlock SME development and the many benefits. The paper's examination revolves around SMEs and entrepreneurial development, employment generation, government policies and financial aid and its availability. With the intention of establishing the relevance of government role in creating vibrant economies via thriving SMEs and its ripple effect on employment generation.
\end{abstract}

Design/methodology/approach - The study adopts a survey design, using a questionnaire for data gathering and percentile, confirmatory factor analysis (CFA) and structural equation modelling (SEM) for data analysis.

Findings - The study established a significant direct relationship between entrepreneurship development and infrastructure development and employment generation. Also, there was a significant direct relationship between government policies and infrastructure development. However, surprisingly, there was an insignificant relationship between government policy and financial aid and accessibility.

(C) Gbemi Oladipo Olaore, Bimbo Onaolapo Adejare and Ekpenyong Ekpenyong Udofia. Published in Rajagiri Management Journal. Published by Emerald Publishing Limited. This article is published under the Creative Commons Attribution (CC BY 4.0) licence. Anyone may reproduce, distribute, translate and create derivative works of this article (for both commercial and non-commercial purposes), subject to full attribution to the original publication and authors. The full terms of this licence may be seen at http://creativecommons.org/licences/by/4.0/legalcode

Corrigendum: It has come to the attention of the publisher that the paper by Gbemi Oladipo Olaore, Bimbo Onaolapo Adejare, Ekpenyong Ekpenyong Udofia (2021) "The gains and pains of small and medium-scale enterprises (SMEs): the way forward for entrepreneurship development in Nigeria," published in Rajagiri Management Journal, did not include the correct affiliation for the first author Gbemi Oladipo Olaore. The correct affiliation has now been published and refers to where the research took place, i.e. at the Department of Business Administration, University of Lagos, Lagos, The authors would like to sincerely apologise for this.

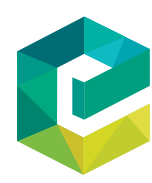

Rajagiri Management Journal Vol. 15 No. 1,2021 pp. $53-68$

Emerald Publishing Limited e-ISSN: 2633-0091 e-ISSN: 2633-0091
p-ISSN: 0972-9968 DOI 10.1108/RAMJ-09-2020-0056 
RAMJ

15,1

Practical implications - The government's role in SMEs' survival and entrepreneurship development is invaluable. The government must live up to their bidding and create an enabling environment to promote SME and entrepreneurship growth. Only this will transform the economy and minimize unemployment to its barest minimum.

Originality/value - The study's research model is an interesting contribution to the body of work in SME and entrepreneurship development. The study is also an original attempt at having a good representation of the South-Western part of Nigeria, as research in high impact journals is usually domiciled in one state.

Keywords SME, Government policies, Employment generation, Entrepreneurship development, Infrastructural development

Paper type Research paper

\section{Introduction}

Small and medium-scale enterprises (SMEs) were classified as essentially backward and inimical to the overall economic development of Nigeria for decades (Sokoto and Abdullahi, 2013). There has been a recurrent feeling that SMEs in Nigeria could only be assisted for social reasons and not for their potential impact on the economy (Oramah et al., 2015). The opinion, held by some citizens and government with little foresight began to change over time as job creation orientation sunk into many, triggering many start-ups that make valuable contributions to the development of the Nigerian economy (Fowosire et al., 2017; Akerejola et al., 2019).

SMEs serve as a catalyst to entrepreneurship, enhanced employment opportunities and stable economic development. Their geographical spread mitigates rural-urban migration and resource utilization (Chima, 2013) and by producing intermediate products, SMEs contribute to industrial supply chains. In recognition of SMEs' economic contributions, specific programmes have been initiated by the government to enhance their development (Busari and Oduwole, 2014). What constitutes an SME differ among studies. However, several indicators such as profits, total capital, market position, number of employees and turnover are considered. That said, a number of employees and turnovers are often applied. Being a Nigerian study, this paper adopts the SMEs development agency of Nigeria (SMEDAN) National policy definition; which states that firms between 10 and 199 employees are small (10-49 staff with assets between N10 and N99.99 million) or medium-scale (50-199 staff with assets between N100 and N999.99 million) (SMEDAN, 2015).

Successive Nigerian government across all tiers have shown interest in financing SMEs by establishing specialized banks, credit agencies and schemes to provide tailored funding for SMEs. Despite the renewed attention and contributions given to SME's by the Nigerian government, SMEs experience numerous problems labelled the Nigerian factor (Akerejola et al., 2019) and surprisingly, financing (single-digit loans) is the apex of them all (Victor et al., 2019). Others include infrastructural deficiency and the absence of a workable policy framework to drive SME establishment and growth (Victor et al., 2019).

\section{Entrepreneurship development in Nigeria: Research context}

Studies conducted on entrepreneurship and its potency to generate employment establishes entrepreneurship relevance in any economy. The economies of developed nations continue to highlight how entrepreneurship is tethered to a nation's development and can do the same to developing nations. Justifying entrepreneurship link to nation-building is its definition as a source of employment generation; with the 
capacity to generate huge rewards that impact the economy positively (Ebitu et al., 2016). Research studies on entrepreneurship have also established its positive relationship with the empowerment of the disadvantaged population segment and employment generation (Oluremi and Gbenga, 2011; Chukwunweike et al., 2015). Nigeria is a nation blessed with diverse business and investment potentials due to the abundant natural and human resources at its disposal. Harnessing these resources requires the ability to identify potentially useful and economically viable fields to venture into. Nigerians have made remarkable success across several industries and have continued to strive for innovative ingenuity in areas such as agriculture, hospitality, solid minerals, haulage, movie production, manufacturing and repairs of mobile phone accessories and the banking industry (Agbeze, 2012).

Despite how blessed Nigeria is; it is one of the poorest countries in the world, coupled with the highest rates of unemployed youth in Sub-Saharan Africa (Afolabi, 2013). Several nations have been able to achieve transformation, reduce the unemployment rate and minimize poverty due to entrepreneurship development, but such cannot really be said of Nigeria (Agwu and Emeti, 2014; Nwokocha and Madu, 2015). According to the National Bureau of Statistics (NBS, 2018), Nigeria's unemployment rate increased from $18.8 \%$ in the third quarter of 2017 to $23.1 \%$ in the third quarter of 2018. Today's unemployment and poverty rates in Nigeria has necessitated the need for SME and entrepreneurship development in Nigeria. This paper seeks to investigate the contribution of SMEs to job creation in Nigeria, availability of financial aid and accessibility to SMEs, as well as a policy framework that supports SME and entrepreneurship development in Nigeria.

\section{Literature review}

\section{Small and medium-scale enterprises versus entrepreneurship}

There's a thin line between Entrepreneurship and SMEs. Entrepreneurship involves the process of innovatively creating or identifying opportunities for new products or improving existing products/services, having in mind the risk associated and the proposed reward (Agwu and Emeti, 2014). Drucker's publication (1985) titled "entrepreneurship and innovation" highlighted the thin line between these concepts. According to Drucker, entrepreneurs create new things while adding greater value which involves a great deal of innovation. While an SME is a business, not necessarily introducing a new product/service. Drucker also stated that to be entrepreneurial, the products/services must be standardized and developed in a unique way, capable of creating a new market, customers and demand. Thus, an entrepreneur most times may start as an SME, but not all SME owners will necessarily become entrepreneurs.

\section{Small and medium-scale enterprise survival}

SMEs can be classified as sustainable when they can overcome daily challenges, both the external and internal environment within which they operate. Prior Research on SMEs accounts for a greater percentage in the growth of employment in many countries around the world. In such countries, SMEs contribute to a significant increase in the gross domestic product while contributions to the gross domestic product by the bigger enterprise are usually stable (Ebitu et al., 2015). The United Nations Industrial Development Organization (UNIDO, 2017) said studies on SMEs' survival in Nigeria show that only $20 \%$ of SMEs manage to survive in Nigeria. The organization further stated that most Nigerians desire to become entrepreneurs and business owners, but only $40 \%$ of the dreamers get to start the proposed business venture, but not more than $20 \%$ actually survive. UNIDO further stated that the government of Nigeria needs to intensify efforts in the area of financing, 
RAMJ

15,1

56

Figure 1.

The pains and gains of SME/

entrepreneurship

development in

Nigeria infrastructure, training and support to SMEs to ensure an increase in the survival rate of SMEs in Nigeria, which, in turn, will accelerate economic growth and development.

Pains and gains of entrepreneurship/small and medium-scale enterprises in Nigeria

Today in Nigeria, a huge number of SMEs were bourne from the unavailability of employment. Nigeria is a nation blessed with many innovative and creative minds but faced with numerous circumstances that impede those creative and innovative minds (Chima, 2013). Figure 1 illustrates how factors such as harsh business environment, fluctuating policies, epileptic power supply (infrastructure), multiple taxations and business registration bottleneck had negatively affected SMEs and Entrepreneurship development in Nigeria as identified by

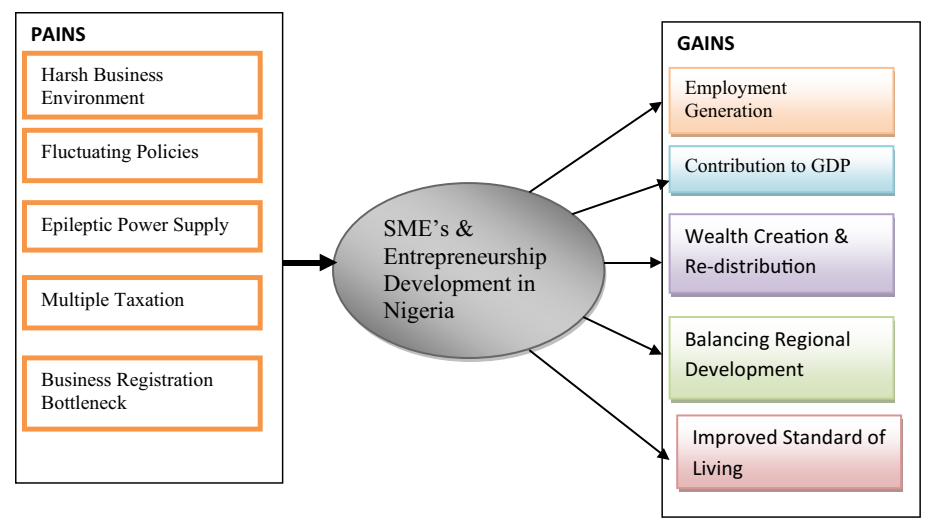

Source: Researchers' (2020) as advanced by literature
Figure 2.

Model of significant direct and indirect relationship between the Pain and Gain of SMEs in Nigeria

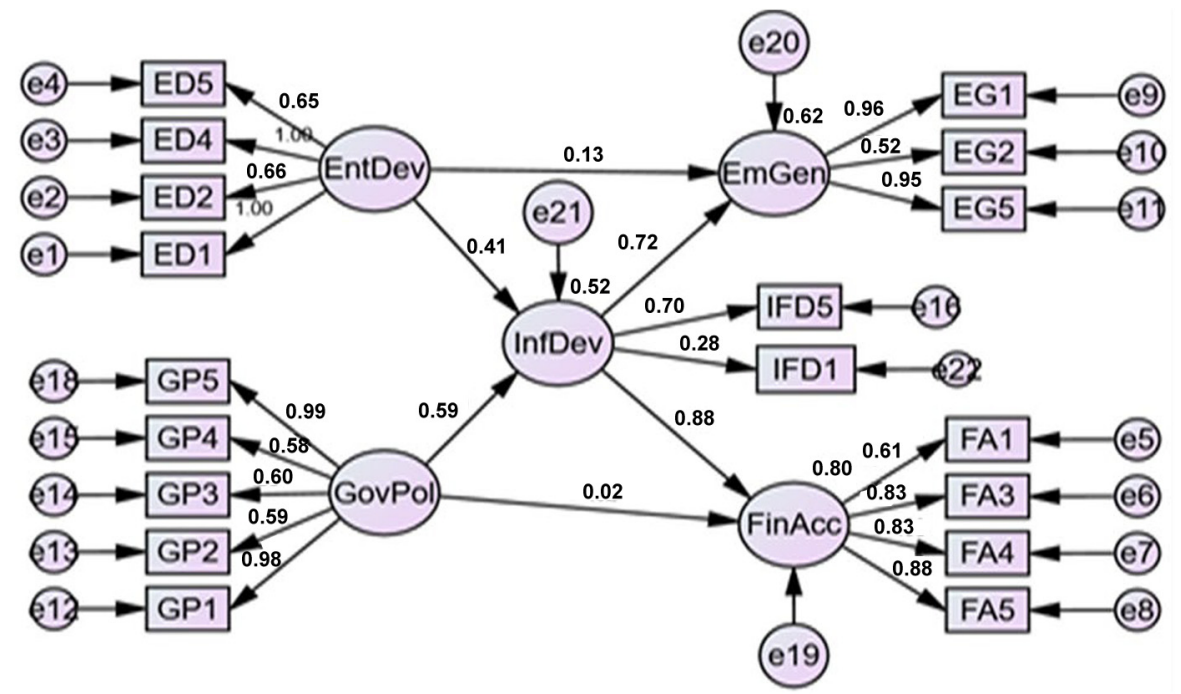


literature. However, this has created research interests in a bid to improve SMEs and entrepreneurship in Nigeria. Consequently, SMEs and entrepreneurship development in Nigeria has led to numerous gains such as employment generation, contribution to GDP, wealth creation and re-distribution, balancing regional development and improved standard of living as advanced by literature.

\section{Underpinning theory}

Opportunity-based entrepreneurship theory

Peter Drucker and Howard Stevenson propounded the opportunity-based entrepreneurship theory. The theory supports a wide range of entrepreneurship research with a conceptual framework (Shane, 2003). The theory states that entrepreneurs do not really cause change, but exploit opportunities created as a result of a change in consumer preference, technology, etc. Drucker (1985) further defines entrepreneur and entrepreneurship as a person who looks for change, responds to the change and seeks to exploits the opportunities. The major unique point from the opportunity construct of Drucker is that entrepreneurs have more eyes for opportunities they see rather than the problems. Stevenson (1990) further extended the opportunity-based theory of Drucker by including resourcefulness into the theory. Stevenson concluded that entrepreneurs seek to exploit every available opportunity without paying much attention to resources currently being controlled by the entrepreneur. The work of Fowosire et al. (2017) also shows the significance of the opportunity-based entrepreneurship theory stating how entrepreneurs strive to identify opportunities and ensure the opportunities are explored and turned into a business venture capable of generating returns for the entrepreneur.

\section{Conceptual framework and hypotheses development}

Small and medium-scale enterprise and employment generation

SMEs have been identified as a major element in Nigeria's drive towards achieving the country's vision 20-2020; global studies acknowledge it as the pivotal pillar to transformation in both developing and developed nations (Odusola, 2008). Beyond financial institutions, the Nigerian government has made several attempts to enhance start-ups through programmes such as Youth Enterprise with Innovation in Nigeria (YouWiN), Women Entrepreneurship Development Programme (WEDP), Youth Corpers Entrepreneurship Development Programme (YCEDP) and The Rural Enterprise Development Initiative (REDI) (Chima, 2013). Also, the government has identified some rural areas capable of generating abundant natural resources to tackle poverty, create wealth and generate employment (Chima, 2013). The study done by Victor et al. (2019) looked at the assessment of SMEs/entrepreneurship and stated it is at its infant stage and has not generated employment the way it should. This prompted $H 1$ and 2 for this study:

Ho1. SME's/Entrepreneurship development significantly contributes positively to employment generation in Nigeria.

Ho2. Nigerian infrastructure system significantly contributes positively to entrepreneurship development in Nigeria.

\section{Small and medium-scale enterprises and government policies in Nigeria}

Busari and Oduwole (2014) opined that the nature of Government policies and their bureaucratic procedures can either positively or negatively affect SMEs and 
RAMJ

15,1

entrepreneurship activity and that government can formulate and implement policies that can support new innovative technological creations, solutions and products, while wrong policies trigger the reverse. Successive governments in Nigeria often amend policies and laws in line with their political party's agenda on SMEs and entrepreneurship which mostly leads to policies neglect and new policies, making a substantial impact on the status, survival and competitiveness of SMEs (Dandago and Usman, 2011). The study done on available infrastructures and the nature of enabling policies to support SME's by Akerejola et al. (2019) gave hints on lack of proper guidelines and enabling policies to enable SME's thrive and survive the harsh business environment; this prompted the formulation of $H 3$ :

Ho3. Government policy significantly contributes positively to Nigerian infrastructure development

\section{Financial aid and accessibility}

While Aluko (2015) recognizes SMEs' role in the growth and development of many nations, Lawal (2014) recognizes its low contribution to GDP and employment. Previous research work is done by Afolabi, M. O. (2013), Sokoto and Abdullahi (2013) and Victor et al. (2019) on SMEs and entrepreneurship has mainly focused on the effect of loan and credit granted by banks to SMEs without comparing how SMEs contribute to GDP or to establish the relationship between the variables. The study done by Iyortsuun (2017) looks at the empirical analysis of the effect of the business incubation process and performance of SMEs while acknowledging their access to financial aid. The study raised critical issues on funds and their accessibility as a constraint. On that premise, the next hypothesis is formulated:

Ho4. Government policies contribute positively to SMEs' financial aid and accessibility in Nigeria.

\section{Mediating role of the Nigerian infrastructural development}

It is tough for Nigeria to improve and sustain economic growth without substantial improvement in infrastructural development in the country (Ebitu et al., 2016), as infrastructural development will expectedly boost entrepreneurial activities and entrepreneurship development (Fowosire et al., 2017). The epileptic power supply is cited as the catalyst for increasing cost of operations and SME mortality in Nigeria (Victor et al., 2019), thus, becoming a business-friendly environment for start-ups, entrepreneurship and innovation, infrastructure must be adequately addressed (Akerejola et al., 2019). Infrastructure as a business propeller informed these mediation hypotheses.

Ho5. Entrepreneurial development through Nigerian infrastructural development has no significant impact on employment generation in Nigeria

Ho6. Entrepreneurial development through Nigerian infrastructural development has no significant impact on SMEs financial aid and accessibility in Nigeria

Ho7. Government policy through Nigerian infrastructural development has no significant impact on SMEs financial aid and accessibility in Nigeria

Ho8. Government policy through Nigerian infrastructural development has no significant impact on employment generation in Nigeria 


\section{Research methodology}

\section{Procedure for data collection}

The study used a questionnaire for data gathering from selected SME owners/managers in five Nigerian states (Lagos, Abuja, Rivers, Oyo and Kano). They were selected for data sampling based on the World Bank report cited by Okelezo (2019), stating that start-ups do better there. Hence, 200 SME owners were selected in Lagos and 100 from others, summing 600 respondents across five states. The study used convenience and judgemental sampling for the selection of SMEs.

The developed questionnaire was guided by the works of Schmid et al. (2018), SuárezÁlvarez et al. (2014), Muñiz et al. (2014) and Pisapia et al. (2016). A five-point Likert scale response type of strongly disagree to strongly agree was used. The questionnaire was assessed by professors of entrepreneurship and SME competitiveness for content and constructs validity, the final output is a reflection of their recommendations. Questionnaire copies distribution took four months (September 2019 to January 2020) and was aided by four postgraduate research assistants who were sensitized on the relevance of selection criteria. Descriptive statistics were used to explain the demography of respondents and confirmatory factor analysis (CFA) and structural equation model (SEM) using SPSS-Amos software were used to test the fitness of the model and analyse the hypotheses. Exploratory factor analysis (EFA) was used to examine the item factor loading and eliminate redundant items from each scale in the study.

Table 1 shows the demographic details of the respondents, out of the 600 questionnaire copies distributed, only 569 was successfully returned and fit for the analysis. Hence, $52.4 \%$ of respondents are male while $47.6 \%$ of respondents are women. The age category shows that $31.1 \%$ are below 30 years, $40.9 \%$ of respondents are between 31 and 40 years, $21.3 \%$ respondents are between 41 and 50 years, while $6.7 \%$ respondents are above 50 years. Similarly, $29.3 \%$ of respondents said worked in the accounting/HR business industry, $18.3 \%$ worked in the education industry, $16.2 \%$ in the food and beverage industry, $11.1 \%$ are in the pharmaceutical industry, $4.9 \%$ in health-care, $19 \%$ in hospitality, while $1.2 \%$ respondents ticked real estate.

Additionally, 30.1\% of SMEs stated that their cost of business capital is below N1 million, $17.6 \%$ were between 1 and 2 million, 25.7\% were between $\mathrm{N} 2.01-\mathrm{N} 3$ million, $22.3 \%$ were between N3.01-4 million, while 4.4\% were above 4 million. Response on staff strength revealed $49.74 \%$ worked in small firms, $22.32 \%$ had between 50 and 99 staff, $15.64 \%$ respondents have between 100 and 149 staff and $12.30 \%$ respondents have between 150 and 199 staff. Finally, the response on years of business operation shows that $43.23 \%$ of respondents are in establishments under 5 years, $38.14 \%$ are between 5 and 10 years and $18.63 \%$ are in operations over 10 years.

\section{Data analysis}

Exploratory factor analysis

The developed questionnaire was subjected to EFA using principal axis factoring to reduce the construct's items and access their factor loading. The constructs item was subjected to oblique rotation because the results from the EFA are expected to be used for conducting CFA and structural equation model (SEM). EFA is important to examine the construct's validity using the varimax-rotation technique to delete redundant items from each variable. Also, the homogeneity and constructs adequacy were examined using the Kaiser-MeyerOlkin (KMO) and the Bartlett's-test of sphericity (BTS) which recommended value of acceptance is set at 0.05 and 0.000 , respectively (Orçan and Yang, 2016). In total, 39 items were subjected to principal axis factoring and only 31 items loaded properly at the third 


\begin{tabular}{|c|c|c|c|c|}
\hline \multirow{3}{*}{$\begin{array}{l}\text { RAMJ } \\
15,1\end{array}$} & \\
\hline & Demographic variable & Frequency & Valid $(\%)$ & Cumulative $(\%)$ \\
\hline & $\begin{array}{l}\text { Gender } \\
\text { Male } \\
\text { Female } \\
\text { Total }\end{array}$ & $\begin{array}{l}298 \\
271 \\
569\end{array}$ & $\begin{array}{l}52.4 \\
47.6 \\
100\end{array}$ & $\begin{array}{c}52.4 \\
100\end{array}$ \\
\hline \multirow[t]{29}{*}{60} & Respondent age & & & \\
\hline & $\begin{array}{l}\text { Below } 30 \text { years } \\
31-40 \text { years }\end{array}$ & $\begin{array}{l}177 \\
233\end{array}$ & $\begin{array}{l}31.1 \\
40.9\end{array}$ & $\begin{array}{l}31.1 \\
72\end{array}$ \\
\hline & $41-50$ years & $\begin{array}{l}205 \\
121\end{array}$ & $\begin{array}{l}40.9 \\
21.3\end{array}$ & 93.3 \\
\hline & Above 50 years & 38 & 6.7 & 100 \\
\hline & Total & 569 & 100 & \\
\hline & Business industry & & & \\
\hline & Accounting and HR services & 167 & 29.3 & 29.3 \\
\hline & Education & 104 & 18.3 & 47.6 \\
\hline & Food and beverage (F\&B) & 92 & 16.2 & 63.8 \\
\hline & Pharmaceutical & 63 & 11.1 & 74.9 \\
\hline & Health-care services & 28 & 4.9 & 79.8 \\
\hline & Hospitality & 108 & 19.0 & 98.8 \\
\hline & Real estate & 7 & 1.2 & 100 \\
\hline & Total & 569 & 100 & \\
\hline & Estimated cost of capital & & & \\
\hline & Below N1 = million & 171 & 30.1 & 30.1 \\
\hline & Between $\mathrm{N} 1=$ million and $\mathrm{N} 2=$ million & 100 & 17.6 & 47.7 \\
\hline & Above $\mathrm{N} 2=$ million to $\mathrm{N} 3=$ million & 146 & 25.7 & 73.4 \\
\hline & Above $\mathrm{N} 3=$ million to $\mathrm{N} 4=$ million & 127 & 22.3 & 95.7 \\
\hline & Above N4 = million & 25 & 4.3 & 100 \\
\hline & Total & 569 & 100 & \\
\hline & Staff strength & & & \\
\hline & Between 10 and 49 employees & 283 & 49.74 & 49.74 \\
\hline & Between 50 and 99 employees & 127 & 22.32 & 72.06 \\
\hline & Between 100 and 149 employees & 89 & 15.64 & 87.70 \\
\hline & Between 150 and 199 employees & 70 & 12.30 & 100 \\
\hline & Total & 569 & 100 & \\
\hline & Years of operation & & & \\
\hline & Below 5 years & 246 & 43.23 & 43.23 \\
\hline \multirow{3}{*}{$\begin{array}{l}\text { Table } \mathbf{1} \text {. } \\
\text { Demographic data } \\
\text { analysis }\end{array}$} & Between 5 and 10 years & 217 & 38.14 & 81.37 \\
\hline & Above 10 years & 106 & 18.63 & 100 \\
\hline & Total & 569 & 100 & \\
\hline
\end{tabular}

loading when the eigenvalue was set to be greater than one. Hence, eight-item failed to load properly and was then deleted from the study. The KMO results from the EFA analysis is 0.738 and Bartlett's-test of sphericity (BTS) is $(\chi 2=23,855.593, p=0.000$ and $<0.05)$. Therefore, we can say that the homogeneity and adequacy of data was achieved in the study.

\section{Unidimensionality}

Unidimensionality measures the extent to which items of a constructs measures what it is meant to measure. This can be done through CFA (Nusair and Hua, 2010). In total 31 items were subjected to CFA and to achieve model fitness, 13 items from the 5 constructs were 
deleted, making only 18 items that were fit for use. Thus, the deleted items per constructs were as follow; entrepreneurship development (ED3, ED6, ED7), Government policy (GP6), Nigeria infrastructural development (IFD2, IFD3, IFD4, IFD6), financial access and aids (FA2, FA6) and employment generation (EG4, EG5, EG6) were deleted. The unidimensionality analysis conducted was confirmatory factor analysis, composite reliability, average variance extracted, Cronbach alpha, factor loading, mean and standard deviation. The reliability of each construct using Cronbach-alpha was above 0.70 which is the recommended threshold for acceptance (Nunnally, 1978), as seen in Table 2. Each of the 18-item factor loading as seen in Table 2 are greater than 0.4 when the eigenvalue is greater than one, therefore, homogeneity was achieved.

Comparative fit index is used to assess whether the study model compares with the nullmodel supposing there are no correlations between the model constructs. As shown in (Table 2) the CFI value for all the constructs is greater than 0.90 , and therefore shows a good fit for the measurement model (Bagozzi and Yi, 2012). Hence, the CFI value shows acceptable model fitness.

Composite Reliability is used to check the internal consistency of each construct with regard to the variance from an observed variable from their latent factor. A construct value that is $\geq 0.70$ has internal consistency and as shown in (Table 2), all five constructs have values between 0.708 and 0.823 . Hence, the composite reliability was achieved from all the constructs.

Average variance extracted is the extent of the variance captured by a construct from the total amount of measurement error experience in a model. According to Maravelakis (2019), the value of the average variance extracted must not be less than 0.50 and going by the result (Table 2) the AVE value range from $0.545-0.745$ and this then supports the unidimensionality of the measurement model. Hence, homogeneity was achieved for the model used to test the hypotheses stated in the study through the structural equation model.

\begin{tabular}{llcccccc}
\hline Measurement items & CFI & Mean & SD & Factor loading & Cronbach's alpha & CR & AVE \\
\hline ED1 & 0.911 & 4.18 & 0.921 & $0.772^{* * * *}$ & 0.863 & 0.731 & 0.656 \\
ED2 & & 4.06 & 0.992 & $0.786^{* * * *}$ & & & \\
ED4 & & 4.21 & 0.818 & $0.852^{* * * *}$ & & & \\
ED5 & 4.05 & 0.995 & $0.779^{* * * *}$ & & & \\
GP1 & 0.924 & 4.00 & 1.034 & $0.773^{* * * *}$ & 0.772 & 0.708 & 0.545 \\
GP2 & & 3.75 & 1.171 & $0.846^{* * * *}$ & & & \\
GP3 & & 3.84 & 1.074 & $0.778^{* * * *}$ & & & \\
GP4 & & 3.76 & 1.175 & $0.859^{* * * *}$ & & & \\
GP5 & & 3.99 & 1.055 & $0.738^{* * * *}$ & & & \\
EG1 & 0.910 & 3.93 & 1.062 & $0.804^{* * * *}$ & 0.863 & 0.718 & 0.603 \\
EG2 & & 3.87 & 1.067 & $0.744^{* * * *}$ & & & \\
EG3 & & 3.74 & 1.215 & $0.798^{* * * *}$ & & & \\
IFD1 & 0.915 & 4.05 & 1.053 & $0.660^{* * * *}$ & 0.850 & 0.721 & 0.745 \\
IFD5 & 3.99 & 1.068 & $0.710^{* * * *}$ & & & \\
FA1 & 0.912 & 3.85 & 1.009 & $0.562^{* * * *}$ & 0.843 & 0.823 & 0.632 \\
FA3 & & 3.77 & 1.068 & $0.614^{* * * *}$ & & & \\
FA4 & & 3.64 & 1.097 & $0.784^{* * * *}$ & & & \\
FA5 & & 4.05 & 0.983 & $0.811^{* * * *}$ & & &
\end{tabular}

Notes: CR: Composite reliability, AVE: Average variance extracted, CFI: Comparative fit indices, $\chi^{2}$ : Chisquare value; $* * *$ (the significance) represents $=000$

Table 2.

Measurement reliability 


\begin{tabular}{l} 
RAMJ \\
15,1 \\
62 \\
\hline
\end{tabular}

\section{Hypotheses testing}

Generally, the CFA results for the model shows a good fitness as all elements of the unidimensionality measures are beyond the acceptable threshold of acceptance as chi-square $\left(X^{2} / \mathrm{df}=2.731\right)$, incremental fits index $(\mathrm{IFI}=0.915)$, comparative fit index $(\mathrm{CFI}=0.902)$, Tucker Lewis index (TLI $=0.908)$ and roots mean square error of approximation (RMSEA $=0.06$ ). Hence, the model shows a perfect fit and is good to test the stated hypotheses using the structural equation model (Nusair and Hua, 2010; Hair et al., 2017).

The study test four direct and four indirect hypotheses. This section shows the indirect relationship among constructs. The result from Table 3, shows that entrepreneurship development has a significant indirect effect on SME's financial aid and accessibility and employment generation with regard to Nigerian infrastructural development as a mediating variable between the constructs $(\beta=0.36,0.30 ; p<0.05)$. This means that entrepreneurship development through Nigerian infrastructural development significantly impacts SMEs' financial aid and accessibility in Nigeria, as well as employment generation. This leads to the acceptance of (Ho5 and Ho6). The findings corroborate the works of Ahmed and Nwankwo (2013) and Shibia and Barako (2017). Also, there is an indirect relationship between government policy (through Nigerian infrastructural development) and SME's financial aid and accessibility and employment generation $(\beta=0.52,0.43 ; p<0.05$, supporting $\mathrm{Ho}_{0}$ and $\mathrm{Ho}$ 8). The indirect impact shows that government policy has been very helpful in helping entrepreneurs gain access to financial aid and thereby creating more employment opportunities for youths in Nigeria (Bastiéa et al., 2016). The findings align with the work of Carsamer (2012) and Galindoa and Mendez (2014) as they found that the central bank of Nigeria's intervention on financial loans to SMEs in Nigeria has been a key support to business growth and employment creation in Nigeria. However, the finding remains inconsistent with the work of Shibia and Barako (2017).

Table 4 shows the hypothesized direct model and examines four direct hypotheses. The first hypothesis tests entrepreneurship development and employment generation and the

Table 3.

Path model and indirect effects

\begin{tabular}{lccl}
\hline Hypothesized model & Standardized indirect coefficient & $p$-value & Remark \\
\hline $\mathrm{ED} \rightarrow \mathrm{IFD} \rightarrow$ FA & 0.364 & 0.001 & Positive and indirect effect \\
$\mathrm{ED} \rightarrow \mathrm{IFD} \rightarrow \mathrm{EG}$ & 0.298 & 0.001 & Positive and indirect effect \\
$\mathrm{GP} \rightarrow \mathrm{IFD} \rightarrow \mathrm{FA}$ & 0.520 & 0.001 & Positive and indirect effect \\
$\mathrm{GP} \rightarrow \mathrm{IFD} \rightarrow \mathrm{EG}$ & 0.426 & 0.001 & Positive and indirect effect
\end{tabular}

Notes: $p<0.05$; where ED = Entrepreneurship development, IFD = Infrastructural development, EG = Employment generation, FA = Financial aid and accessibility, GP = Government policy

Table 4.

Path model and direct effects

\begin{tabular}{lccc}
\hline Hypothesized model & Standardized coefficient & $p$-value & Remark \\
\hline $\mathrm{ED} \rightarrow \mathrm{IFD}$ & 0.412 & 0.000 & Significant \\
$\mathrm{ED} \rightarrow \mathrm{EG}$ & 0.129 & 0.001 & Significant \\
$\mathrm{GP} \rightarrow \mathrm{IFD}$ & 0.589 & 0.000 & Significant \\
$\mathrm{GP} \rightarrow$ FA & 0.016 & 0.764 & Not significant
\end{tabular}

Notes: $p<0.05$; where ED = Entrepreneurship development, IFD = Infrastructural development, EG = Employment generation, FA = Financial aid and accessibility, GP = Government policy 
result shows $(t=3.250 ; p<0.05$ and $\beta=0.13$ ). This, therefore, shows that entrepreneurship development contributes positively to employment opportunities in Nigeria. This corroborates the works of Carsamer (2012) and Nambisan and Baron (2013), Shibia and Barako (2017), who found that strong economies rely on entrepreneurship development. The second hypothesis examined entrepreneurship development and the Nigerian infrastructural development relationship and the result revealed acceptance at $(t=9.329$; $p<0.05$ and $\beta=0.41$ ). This may be as a result of the fact that entrepreneurs pay tax and Nigerian infrastructure is being developed through tax payer's money, hence, the acceptance of the hypothesis. The finding, however, does not align with the work of Galv et al. (2018). The third hypothesis examined government policy and Nigerian infrastructural development and the result revealed acceptance at $(t=12.371 ; p<0.05$ and $\beta=0.59$ ). The last direct hypothesis examined government policy and SME's access to financial aid and the result revealed nonacceptance at $(t=0.300 ; p<0.05$ and $\beta=0.02$ ). This may be due to the inconsistency in government policy with regard to entrepreneurship supports on financial aid and accessibility leading to business growth and the eventual creation of employment opportunities in the country as found in many developed economy/country who depends on entrepreneurship for growth and development (Shibia and Barako, 2017). This finding is, however, in alignment with Bruton et al. (2013), who found a similar but negative relationship existing between government policy and financial accessibility to loans by SMEs in the country. Thus, three direct hypotheses were significant and one insignificant.

\section{Discussion of findings}

The finding of the study has been able to show the importance of entrepreneurship development to employment creation in Nigeria. Entrepreneurship development has been the major driver of growth for most developed countries (Estay et al., 2013) but Nigeria has not fully harnessed the opportunities embedded in its investment. This is why we experience setbacks in creating employment opportunities, eradicating poverty and improving the standard of living (Bruton et al., 2010). This finding is, however, in tandem with the work of Carsamer (2012) and Nambisan and Baron (2013). The finding also aligns with the entrepreneurship opportunity theory which says that government does not provide jobs, they provide the enabling environment to aid businesses who then creates the jobs. Unemployment is a major problem for any developing economy like Nigeria (Light and Bhachu, 2017), providing lasting solutions to this menace (unemployment) is paramount to all stakeholders (Government, public and private institutions, societies, families and individuals) to enable a sustainable progressive and productive ecosystem (Estay et al., 2013).

Creating an enabling environment for entrepreneurship to thrive is the sole responsibility of the government, especially in the area of infrastructural development. The study findings show that Nigerian infrastructural development contributes positively to entrepreneurship development and aligns with Galv et al. (2018) and negates findings from Bruton et al. (2013). Entrepreneurship development in Nigeria suffers many constraints with respect to infrastructure development such as electricity, transportation system and good roads (Atiase et al., 2017). This setback can be traced to inconsistent government policy and leadership in the country (Chigwenya and Mudzengerere, 2013). When there is a lack of basic amenities to aid the smooth running of the business and enhance SME's productivity, entrepreneurship development is stifled.

Furthermore, multiple taxations, business registration bottlenecks and ease of doing business in Nigeria still serve as major hurdles to SMEs (Atiase et al., 2017). Contrastingly, while stakeholders want a self-sufficient society; they lack the will to promote what can make this happen fast. There is no doubt that SMEs have the potential to generate more 
RAMJ

15,1

employment and reduce the poverty in Africa if fully harnessed by all stakeholders as revealed by this study and that of Sergi et al. (2019).

This study shows a positive relationship between government policy and Nigerian infrastructural development, but a negative relationship with SME's financial aid and accessibility. In the work of Sergi et al. (2019), entrepreneurship in developed countries leverage so many amenities provided by the government to support business growth and among them is financial support. Developing nations, especially Nigeria need to learn to become intentional at providing financial aids to indigenous entrepreneurs with little or no interest to aid entrepreneurship growth, employment opportunities, poverty minimization and the standard of living (Atiase et al., 2017).

Poverty and hunger are on the rise and entrepreneurship development is a major solution to these problems in Nigeria (Iyortsuun, 2017). Unemployment and frustration have led many to hopelessness among many young majorities of Nigerian citizens who now resort to thuggery, violence and crime as a means to earn a daily living, as they are not gainfully employed. They are not employed, not because they lack qualifications but because the system has not worked optimally which has left many vibrant graduates and youths in Nigeria to be displaced economically (Iyortsuun, 2017). This is a situation that negates the Millennium Development Goals for 2015, which was proposed to halve the proportion of people living in extreme poverty and also to reduce hunger, respectively (Acs et al., 2017).

\section{Conclusion}

The study was carried out to examine the gains and pains of SMEs and provide an insightful way forward for entrepreneurship development in Nigeria. The study investigated the contribution of SMEs to job creation in Nigeria, availability of financial aid and accessibility to SMEs growth and policy framework that support SMEs and entrepreneurship development in Nigeria.

The significance of Entrepreneurship and SMEs to drive economic development must not be jettisoned as an effort at all levels of government in Nigeria must continue to be geared towards it (Shibia and Barako, 2017). Consequently, SMEs and entrepreneurship has contributed significantly to employment generation in Nigeria, but still very low compared to expectations as the rise of unemployment bedeviling Nigeria is still high and the figure for unemployment is increasing by the day (Victor et al., 2019). The study also concludes that government policies have positively driven and encouraged further development of SMEs and entrepreneurship in Nigeria and also financial aid and accessibility has created room for entrepreneurs and business owners to get access to funding. In other words, entrepreneurship and SMEs have been the major driving force for the growth and development recorded in Nigeria so far.

This shows that there is a need to devote more attention to enhance the further economic development of Nigeria and must be nurtured and cared for by successive governments by making funds available and accessible at a lower interest rate to SMEs and entrepreneurs (Nambisan and Baron, 2013). Considering the huge role and significance of SMEs and entrepreneurship, there is a need for government to channel more resources to enhance local material utilization and technology which can also play a major role in government efforts towards industrialization. It is the duty of the government to also review and further articulate current policies to empower and strengthen the growth and development of SMEs, creating enabling environment for SMEs to thrive thereby increasing employment generation and reducing the burden of unemployment in the country (Sergi et al., 2019). 


\section{Recommendations}

Nigerian Government must enact policies that reduce the pains and enhances the gains of SMEs and entrepreneurship development to improve the economy. These policies should have periodic reviews to address their current challenges.

Policies and incentives promoting rural SMEs should be enacted to address rural-urban migration and rural area development and economic growth.

Small business loan interest rates and accessibility, as well as monitoring mechanisms for loan deployment, should be holistically reviewed to encourage SMEs and entrepreneurs and ensure productive use of loans.

The government should ensure a comprehensive national presence of finance institutions aimed at funding SMEs and entrepreneurs with feasible business ideas.

Secondary and tertiary institution curriculum should include entrepreneurship education to stimulate the mindset of the youths from a very young age towards entrepreneurship.

The Nigerian government should also establish Business Development Services (BDS) across the country where SMEs and entrepreneurs can get a wide range of business growth to consult for minimal cost.

\section{References}

Acs, J., Szerb, L., Autio, E. and Lloyd, A. (2017), Global Entrepreneurship Index, The Global Entrepreneurship and Development Institute, Washington, DC, pp. 82-86.

Afolabi, M.O. (2013), "Growth effect of small and medium enterprises (SMEs) financing in Nigeria", Journal of African Macroeconomic Review, Vol. 3 No. 1, pp. 36-46.

Agbeze, C. (2012), "Entrepreneurship: the need to create wealth: why not now?", Ohafia Today, Vol. 2 No. 32, pp. 7-12.

Agwu, M.O. and Emeti, C.I. (2014), "Issues, challenges and prospects of small and medium scale enterprises (SMEs) in Port-Harcourt city”, European Journal of Sustainable Development, Vol. 3 No. 1, pp. 101-101.

Ahmed, A. and Nwankwo, S. (2013), "Entrepreneurship development in Africa: an overview", World Journal of Entrepreneurship, Management and Sustainable Development, Vol. 9 Nos 2/3.

Akerejola, W.O., Okpara, E.U., Ohikhena, P. and Emenike, P.O. (2019), "Availability of infrastructure and adoption of point of sales of selected small and medium enterprises (SMEs) in Lagos state", Nigeria. International Journal of Academic Research in Business and Social Sciences, Vol. 9 No. 1, pp. $137-150$.

Aluko, M.O. (2015), "Growth effect of small and medium enterprises (SMEs) financing in Nigeria", Journal of African Macroeconomic Review, Vol. 3 No. 1, pp. 193-205.

Atiase, V.Y., Mahmood, S., Wang, Y. and Botchie, D. (2017), "Developing entrepreneurship in Africa: investigating critical resource challenges", Journal of Small Business and Enterprise Development, doi: 10.1108/JSBED-03-2017-0084.

Bagozzi, R.P. and Yi, Y. (2012), "Specification, evaluation, and interpretation of structural equation models", Journal of the Academy of Marketing Science, Vol. 40 No. 1, pp. 8-34.

Bastiéa, F., Cussya, P. and Nadant, L.A. (2016), "Network or independent business? Entrepreneurs' human, social and financial capital as determinants of mode of entry", Managerial and Decision Economics, Vol. 37 No. 3, pp. 167-181.

Bruton, D., Ketchen, J. and Ireland, R.D. (2013), “Entrepreneurship as a solution to poverty”, Journal of Business Venturing, Vol. 28 No. 6, pp. 683-689.

Bruton, G., Ahlstrom, D. and Li, H.L. (2010), "Institutional theory and entrepreneurship: where are we now and where do we need to move in the future?", Entrepreneurship Theory and Practice, Vol. 34 No. 3, pp. 421-440. 
RAMJ

15,1

Busari, O.S. and Oduwole, W.K. (2014), "Marketing challenges and opportunities confronting small scale businesses in Nigeria-a lesson for young entreprenueur", Marketing, Vol. 5 No. 1, pp. 21-29.

Carsamer, E. (2012), "Promoting entrepreneurial development among SMEs through financial management in Ghana", International Journal of Economic Perspectives, Vol. 6 No. 2, pp. 188-197.

Chigwenya, A. and Mudzengerere, F.H. (2013), "The small and medium enterprises policy in Zimbabwe: a narrative of strides taken to mainstream the informal sector activities in urban local authorities in Zimbabwe", International Journal of Politics and Good Governance, Vol. 4 No. 4.

Chima, M. (2013), "Small and medium enterprises (SMEs) in Nigeria: problems and prospects", available at: http://martinslibrary.blogspot.com/2013/09/small-and-medium-enterprises-smes-in.html

Chukwunweike, N.V., Ani, M.I., Ocheje, F.J. and Akunna, O.V. (2015), "Production subcontracting: a strategy for the survival of small and medium scale industries in Nigeria", Mediterranean Journal of Social Sciences, Vol. 6 No. 4, p. 639.

Dandago, K.I. and Usman, A.Y. (2011), "Assessment of government industrialisation policies on promoting the growth of small scale industries in Nigeria", Paper Presented at the 2011 BenAfrica Conference Zanzibar, Tanzania, Department of Economics, Kaduna State University, Kaduna-Nigeria.

Drucker, P. (1985), Innovation and Entrepreneurship, Harper and Row Publishers, New York, NY.

Ebitu, E.T., Glory, B. and Alfred, U.J. (2016), "An appraisal of Nigeria's micro, small and medium enterprises (msmes): growth, challenges and prospects", British Journal of Marketing Studies, Vol. 4 No. 5, pp. 21-36.

Ebitu, E.T., Ufot, J.A. and Olom, P.A. (2015), "Marketing problems and the performance of selected small and medium enterprises (SMEs) in Southern senatorial district of Cross River state, Nigeria", American International Journal of Contemporary Research, Vol. 5 No. 5, pp. 70-76.

Estay, C., Durrieu, F. and Akhter, M. (2013), "Entrepreneurship: from motivation to start-up”, Journal of International Entrepreneurship, Vol. 11 No. 3, pp. 243-267.

Fowosire, R.A., Idris, O.Y. and Opoola, E. (2017), "Technopreneurship: a view of technology", Innovations and Entrepreneurship. Global Journal of Researches in Engineering, Vol. 17 No. 7, pp. 41-46.

Galindoa, M. and Mendez, M.T. (2014), "Entrepreneurship, economic growth, and innovation: Are feedback effects at work?", Journal of Business Research, Vol. 67 No. 5, pp. 825-829.

Galv, A., Ferreira, J.J. and Marques, C. (2018), "Entrepreneurship education and training as facilitators of regional development: a systematic literature review", Journal of Small Business and Enterprise Development, Vol. 25 No. 1, pp. 17-40.

Hair, J., Hult, G., Ringle, C. and Sarstedt, M. (2017), A Primer on Partial Least Squares Structural Equation Modeling PLS-SEM, SAGE, Los Angeles.

Iyortsuun, A.S. (2017), "An empirical analysis of the effect of business incubation process on firm performance in Nigeria", Journal of Small Business and Entrepreneurship, Vol. 29 No. 6, pp. 433-459.

Lawal, B.A. (2014), "Banking sector and the development of SMEs in Osun state", Research Journal of Finance and Accounting, Vol. 5 No. 4, pp. 21-32.

Light, I. and Bhachu, P. (2017), Immigration and Entrepreneurship: Culture, Capital and Ethnic Networks, Routledge.

Maravelakis, P. (2019), "The use of statistics in social sciences", Journal of Humanities and Applied Social Sciences, Vol. 1 No. 2, pp. 87-97, doi: 10.1108/JHASS-08-2019-0038.

Muñiz, J., Suárez-Álvarez, J., Pedrosa, I., Fonseca-Pedrero, E. and García-Cueto, E. (2014), "Enterprising personality profile in youth: components and assessment", Psicothema, Vol. 26 No. 4, pp. 545-553, doi: 10.7334/psicothema2014.182. 
Nambisan, S. and Baron, A.R. (2013), "Entrepreneurship in innovation ecosystems: entrepreneurs' selfregulatory processes and their implications for new venture success", Entrepreneurship Theory and Practice, Vol. 37 No. 5, pp. 1071-1097.

National Bureau of Statistics (2018), Nigerian Domestic Product Report.

\section{Small and medium-scale enterprises}

Nunnally, J.C. (1978), Psychometric Theory, 1st ed., Mcgraw Hill, New York, NY.

Nusair, K. and Hua, N. (2010), "Comparative assessment of structural equation modeling and multiple regression research methodologies: e-commerce context", Tourism Management, Vol. 31 No. 3, pp. 314-324, doi: 10.1016/j.tourman.2009.03.010.

Nwokocha, V.C. and Madu, I.A. (2015), "Influence of subcontracting constraints on the performance of manufacturing industries in Nigeria", Production and Manufacturing Research, Vol. 3 No. 1, pp. 343-354.

Odusola, A. (2008), "The nexus between global competitiveness and Nigeria's vision 20: 2020", The Nigerian Journal of Economic and Social Studies, Vol. 50 No. 3, pp. 281-305.

Okelezo, D. (2019), "The best five cities in Nigeria for start-ups and entrepreneur", available at: https:// cfamedia.ng/5-best-cities-nigeria-start-ups-and-entrepreneurs/

Oluremi, H.A. and Gbenga, M.A. (2011), "Environmental factors and entrepreneurship development in Nigeria", Journal of Sustainable Development in Africa, Vol. 13 No. 4.

Oramah, I.T., Richards, J.P., Summers, R., Garvin, T. and McGee, T. (2015), "Artisanal and small-scale mining in Nigeria: experiences from Niger, Nasarawa and Plateau states", The Extractive Industries and Society, Vol. 2 No. 4, pp. 694-703.

Orçan, F. and Yang, Y. (2016), "A note on the use of item parceling in structural equation modeling with missing data", Journal of Measurement and Evaluation in Education and Psychology, Vol. 7 No. 1, pp. 59-72, doi: 10.21031/epod.88204.

Pisapia, J., Feit, K., Morris, J. and Jelenc, L. (2016), "Strengthening the link between entrepreneurial proclivities and entrepreneurial outcomes: a confirmatory factor analysis of the entrepreneurial dispositions scale (EDS)", SEAANZ (Small Enterprise Association of Australia and New Zealand) National Small Business Conference, 29th Annual Conference, Melbourne, Australia.

Schmid, S., Bohnenberger, M.C., Panizzon, M., Marcon, S.R., Toivonen, E. and Lampinen, M. (2018), "Student's entrepreneurial behaviour: an eight-construct scale validation", International Journal of Entrepreneurship, Vol. 22 No. 2.

Sergi, B.S., Popkova, E.G., Bogoviz, A.V. and Ragulina, J.V. (2019), "Entrepreneurship and economic growth: the experience of developed and developing countries", Entrepreneurship and Development in the 21st Century, pp. 3-32.

Shane, S.A. (2003), A General Theory of Entrepreneurship: The Individual-Opportunity Nexus, Edward Elgar, Cheltenham.

Shibia, G.A. and Barako, G.D. (2017), "Determinants of micro and small enterprises growth in Kenya", Journal of Small Business and Enterprise Development, Vol. 24 No. 1, pp. 105-118.

SMEDAN (2015), "Federal republic of Nigeria national policy on micro, small, and medium scale enterprises", available at: www.smedan.gov.ng/images/PDF/NATIONAL-POLICY-ONMSMEsNew.pdf (accessed 23 September 2019).

Sokoto, A.A. and Abdullahi, Y.Z. (2013), "Strengthening small and medium enterprises (SMEs) as a strategy for poverty reduction in North Western Nigeria", American Journal of Humanities and Social Sciences, Vol. 1 No. 3, pp. 189-201.

Stevenson, L. (1990), "Some methodological problems associated with researching women entrepreneurs", Journal of Business Ethics, Vol. 9, pp. 439-446.

Suárez-Álvarez, J., Pedrosa, I., García-Cueto, E. and Muñiz, J. (2014), "Screening enterprising personality in youth: an empirical model”, Spanish Journal of Psychology, Vol. 17, doi: 10.1017/sip.2014. 
RAMJ

15,1

68

UNIDO (2017), "A paper presented by Mr Afif barhoumi during a ceremony of a four-day training programme organised by UNIDO ITPO Nigeria for selected federal government agencies".

Victor, C.N., Christopher, N. and Ignatius, A.M. (2019), "The role of subcontracting on innovation: an assessment of small and medium enterprises in Nigeria", Production and Manufacturing Research Journal, Vol. 7 No. 1, pp. 88-108.

\section{Further reading}

Adejumo, G. (2001), "Indigenous entrepreneurship development in Nigeria: characteristics, problems and prospects", Advances in Management: Journal of Department of Business Administration, Vol. 2 No. 1, pp. 112-122.

Klyton, V.A. and Rutabayiro-Ngoga, S. (2017), "SME finance and the construction of value in Rwanda", Journal of Small Business and Enterprise Development, doi: 10.1108/JSBED-022017-0046.

Shimeles, A. and Salami, A.O. (2015), "Employment effects of multilateral development bank support: the case of the African development bank", African Development Review, Vol. 27 No. S1, pp. 31-43.

\section{About the authors}

Gbemi Oladipo Olaore is a graduate of the University of Ado Ekiti, Nigeria, where he earned his BSc in Business Administration and management. He proceeded to the University of Lagos, Nigeria, where he bagged his MSc in management. He is currently a $\mathrm{PhD}$ scholar and has published in both local and international journal outlets. His research interests are, but not limited to Entrepreneurship/ SMEs Development, Branding and Rebranding, Sustainable SMEs in the health sector, Internalization, Innovation management, Sustainable SMEs Development, Succession planning, strategic management, and the role of institutional environment SME performance in emerging economies.

Bimbo Onaolapo Adejare is a Master degree (MSc Management) holder from the University of Lagos. He earned his first degree (BSc in Business Administration) at Osun State University. He is a member of the Nigerian Institute of Management and the Institute of Strategic Management of Nigeria as a Chartered manager and Strategic Manager respectively. He is a Doctoral Research Scholar at the University of Minho, School of Economics and Management. He has collaborated on several research works and his area of research interest are but not limited to Entrepreneurship Internalization, Managing Nonmarket Risk, Innovation Management, Firm Dynamic Capabilities, Business Model Innovation, Sustainable SMEs development, and Succession Planning. Bimbo Adejare has attended and presented in both local and international conferences. Bimbo Onaolapo Adejare is the corresponding author and can be contacted at: bimboadejare@gmail.com

Ekpenyong Ekpenyong Udofia is an operations and supply chain management enthusiast, with a BSc in Business Administration and an MSc degree in production and operations management, both from the University of Lagos. He is currently working for a consulting firm in Lagos, Nigeria, as the operations manager, where he is actively involved in management research and consult. He is a Doctoral research scholar with publications in both local and international journal outlets, and he is interested in researches in Quality management, Supply chain management, Logistics management, Innovation management, Lean manufacturing, Business environment uncertainty, Productivity, and New product development.

For instructions on how to order reprints of this article, please visit our website:

www.emeraldgrouppublishing.com/licensing/reprints.htm

Or contact us for further details: permissions@emeraldinsight.com 